\title{
Economic Growth Arguments: The Role of the Capital Market
}

\author{
Oke J. A., Okunlola F. A., Suberu O. J. \\ Department of Banking and Finance, Faculty of Financial Management Studies, The Polytechnic Ibadan, University of Ibadan, Ibadan, \\ Nigeria
}

\section{Email address:}

un_va@yahoo.com (Suberu O. J.)

\section{To cite this article:}

Oke J. A, Okunlola F. A., Suberu O. J. Economic Growth Arguments: The Role of the Capital Market. International Journal of Economics, Finance and Management Sciences. Vol. 5, No. 3, 2017, pp. 139-145. doi: 10.11648/j.ijefm.20170503.12

Received: December 24, 2016; Accepted: January 4, 2017; Published: April 14, 2017

\begin{abstract}
The study has examined critically the vital role capital market can play at improving economic growth. The total market capitalization and all share index were used as proxies for the independent variables while gross domestic product was used as proxy for economic growth, serving as dependent variable. The study considered the activities at the capital market as having value chain consequences that encapsulate the wheel of growth of the economy. As such, to test the validity the OLS regression analysis technique was adopted for empirical analysis. The result indicates a statistically significant relationship with total market capitalization while all share index showed a statistically insignificant relationship. In all, more instruments were recommended to be introduced in the market if the capital market would fully perform its function as lubricating channel of economic growth.
\end{abstract}

Keywords: Capitalization, All Share Index, Securities, Instruments, GDP

\section{Introduction}

Most economic growth arguments are rooted in the discussion of macroeconomic variables. Apparently, these variables include but not limited to full employment, relatively stable or single digit inflation, price stability, production (country's output) among others. Achieving these macroeconomic objectives is cardinal to the monetary authorities in any nation. In this aspiration, it is pertinent that such aspiring economy must operate in an atmosphere of sound financial system. In order words, no nation thrives without the establishment of a sound, viable, sophisticated financial system of which the capital market is major.

Similarly, most economic growth nexus with the capital market are discussed often under theories such as financial intermediation, Capital Asset Pricing theory (CAPM), Arbitrage Pricing Theory (APT), fractal model hypothesis, profit and residual theory of investment, the Solow growth model, endogenous growth theory etc.

Thus, capital market is a segment of financial system that accommodates certain institutions for the creation, custodianship, distribution and exchange of financial assets and management of long - term liabilities and gross fixed capital formation (Osaze 2007; Onyeiwu, 2012 Ogunbiyi and Okunlola 2013a, 2015b; Okunlola, Dangor and Gbanador, 2013).

Further, Ogunbiyi and Okunlola (2013) opined that investments that promote economic growth require long term funding, far longer than the duration for which most savers are willing to commit their funds. As a consequence, what the capital market does is to synchronize the divergent preferences of portfolio managers and financial institution and those of savers by mobilizing long-term funds for portfolio managers and financial institutions while providing avenues for savers to divest when the need arises through the secondary market without affecting the operation of the firm. As such, through the activities of the secondary market, the capital market converts long-term or perpetual investment into liquid assets for onward investments purposes cum growth economically (Stanford 1999; Binos 2001; NSMA2002, 2009; CBN 2007, 2009 and 2010; Osaze 2007; Ndi-Okereke 2006; Riman and Eyo 2008; Oluwatoyin and Gbadebo 2009; Okpara 2010; Campbell 2010; Ashaolu and Ogunmuyiwa 2010; Okunlola, et al 2013; Ogunbiyi and Okunlola, 2013).

Hitherto, the study shall seek to examine the link between 
most economic growth debates and the role the capital market is expected to play. Sequentially, the study is structured into four sections including the introduction. Section two is the review of literature, followed by methodology in section three, presentation of result, analysis, conclusion and recommendations in section four.

\section{Literature Review}

\subsection{Theoretical Underpinning}

Basically, capital market theories relate to that generic term used for the analysis of securities. These securities are stocks, shares, bonds, debentures etc traded on the floor of the stock exchange. As a nexus with economic growth, the volume, values, new issues, capital formation and all share index are parameters at determining economic viability. That is, ease of capital formation, intermediation, number and availability of instruments, ease of transactions and transaction formalities, entry access among others. Ab initio, all of these parameters speak of the available potentials and growth of the economy.

\subsection{Financial Intermediation Theory}

Financial intermediation is a mechanism for the mobilization and transfer of savings from the fund owners to the users of the funds for further investment purposes. By implication, it is a trade-off concept whereby funds are mobilized from surplus to deficit economic units and the deficit user utilizes it for investment purposes in other to yield optimal benefits and attendant economic growth (Asaolu, and Ogunmuyiwa, 2010). For this to take place, there is an influence by both endogenous and exogenous factors such as level of financial growth, interest rate, and financial sector stability and lending which is determined by lending rates, level of domestic investment, demand for fund by the economic agents and inflation.

In this wise, financial intermediation covers the activities of capital market, like managing the payment system, collection and transfer of savings, investment in long term financial securities, activities covering the financial market, such as foreign exchange market, and future market. (Asaolu, and Ogunmuyiwa, 2010). It also provides financial framework that provides the medium of exchange for specialization, mobilization, and transfer of savings from the generators of funds to those who use it for investment purposes in the economic system where it will yield highest return. This arrangement enhances productive activities and positively influences aggregate capital formation needed in the economy (Ashaolu and Ogunmuyiwa 2010; Okunlola, et al 2013; Ogunbiyi and Okunlola, 2013).

\subsubsection{Solow Economic Growth Hypothesis}

One of the earliest models of economic growth was developed by Solow in 1956. Solow's model is set in a neoclassical framework where it is assumed that all prices have adjusted to clear all the markets (i.e., supply is equal to demand) and incentives have generated efficient outcomes. In the simplest form, three factors determine aggregate output: labour, capital and technology.

Growth models concentrate on explaining the behaviour of potential output, which is output achieved with a given technology and the full employment of other factors. Naturally, they focus on the effects, over time, of changes in labour, capital and technology. Changes in labour accordingly can be induced by changes in the population or in the proportion of the people available for work. Whereas changes in existing productive capital depend on net investment, that is gross investment minus depreciation of existing capital. As long as net investment is positive, capital will grow and production (output) growth would follow. As such, technology combines with the other inputs, labour and capital, to produce output. Hence, in the absence of changes in one of the two inputs, growth is assumed to come from change in technology. Although this growth model do not explicitly consider the financial market in the short run but basically takes general economic growth into considerations. However, in the long run Solow's model allows for adjustments thereafter. As such total saving is used to make capital grow exactly at the same rate as population. Similarly, Solow's model opined in the long run that once the level of capital per worker is stabilized, output per worker is stabilized, both capital and output grows at the same rate. This is known as the balanced growth argument. This assertion of Solow growth model has been used extensively as a basis for empirical investigations on the sources of growth. That is, growth depends on capital accumulation thereby increasing the stocks of capital goods to expand productive capacity. A combination of capital deepening and technological improvements explains major trends in economic growth; this will help in boosting capital market activities. (Solow, 1965).

\subsubsection{Endogenous Growth Theory}

In the Solow model growth can arise only through continuous changes in technology and therefore is purely exogenous. Indeed savings by itself does not generate growth and other school of thought has named the Solow hypothesis as exogeneity assumption. In their defence, Endogenous growth theory described two approaches to economic growth. Accordingly, there is one that sees all inputs as reproducible and the other that is based on externalities. In one particular case the externalities takes the form of human capital building. In both approaches, the savings rate plays a key role in the growth of capital and output per worker. The first approach is the so-called AK-model. It is based on the hypothesis that all input are reproducible and in particular the state of knowledge through research and development. Moreover, an increase in the savings rate permanently raises the rate of growth of capital and output per worker. The second approach introduces externalities in the production process such that an increase in the output level by one firm affects positively factor productivity in another firm. Not all types of externalities are, however, necessary linked to the 
production process and one type of externalities which is of particular interest concerns labour. In this model, labour is endogenously determined and it is not just the quantity of labour, which is relevant, but its quality (Stern, 1991). For instance, households can save by investing in human capital in addition to saving to invest in physical capital. In doing so, households produce labour with skills, labour that can create ideas and handle sophisticated technologies. The theoretical set-up is very similar to that of the Solow model though, but with human capital deliberately accumulated (i.e. endogenous). Endogenous growth theory says that government policy to increase capital or foster right kinds of investment in physical capital can permanently raise economic growth. (Ogunibiyi and Okulola, 2013; Okpara, 2010; Oluwatoyin, and Gbadebo, 2009).

\subsubsection{McKinnon (1973) and Shaw Theory (1973)}

This theory remark that growth is hinged on the interplay of financial market activities in an economy. As such McKinnon (1973) and Shaw 1973 are of the views that financial market sophistication increases the level of intermediation in a given economy.

\subsection{Capital Market and Economic Growth Nexus Review}

The Central Bank of Nigeria (2010), Ogunibiyi and Okulola, (2013) pointed out the activities of the capital market in relations to its contribution to stimulating economic growth. Accordingly, the volume and value of traded securities rose by 6.3 and 3.9 per cent to 28.9 billion shares and $=\mathrm{N}=207.1$ billion respectively in 2009 , compared with 27.2 billion shares and $=\mathrm{N}=199.4$ billion in the second quarter 2010. In the first nine months of the year, total turnover volume and value stood at 75.3 billion shares and $=\mathrm{N}=508.7$ billion, respectively. The banking sub-sector was the most active on the Ex-change with traded volume of 15.4 billion shares valued at $=\mathrm{N}=135.4$ billion exchanged in 246,837 deals. Transactions during the period included 100 units of Lagos State Fixed Rate Bond worth $=\mathrm{N}=119,530$. Also, securities listed in the exchange rose to 294 from its 288 in 2005 which indicate a positive development to the exchange and the economy at large. The essence of this is that more people have become aware of the stock market opportunities of driving their business. The implication for the economy as a whole is an implied effect for development. Although the total market capitalization of these 294 listed securities declined by 11.4 per cent to $=\mathrm{N}=7.8$ trillion from the preceding quarter's level. The fall in market capitalization was attributed to the price losses recorded by the highly capitalized stocks and the recent global economic crisis. Out of the 294 listed equities, 211 accounted for $=\mathrm{N}=5.1$ trillion or 65.8 per cent of the total market capitalization while 34.2 percent account for others (CBN: 2009). The Nigerian Stock Exchange (NSE) All-Share Index, which opened at 26, 861.55, closed at 22,065.00, representing a decline of 17.9 per cent from the level in the preceding quarter. Relative to the closing value of $31,450.78$ on December 31, 2008, the year-to-date decline in the NSE
All-Share-Index stood at 29.8 per cent.

The activities of the capital market is further worsening by the economic downturn that is currently been witnessed by the country owing to decline in its oil sales. This has had considerable impact on the overall performance of activities at the market and as such it attendant effect on economic growth cannot be overemphasized. Specifically also, the recent delay in budget approval by the federal government adversely affect inflows such that activities in the market is further impaired.

\subsection{Some Empirical Literature}

Ezirim, Adebajo, Elike and Muoghalu (2009), reviewed the Nigerian capital market growth and information technology utilizing the modified Gompertz diffusion model in investigating the effects. Findings shows that growth in total volume and value of shares traded is significantly affected by communication technology. Accordingly, they argued that the number of securities listed on the Stock Exchange as well as the growth in federal and state government bonds does not appear to have any significant relationship with the adoption of information and communication technology that private debt stock appears to have been significantly affected by information and communications technology especially in respect of increase in the number of stockbrokers and access to ICT. Generally, they concluded that information technology (IT) has contributed to growth of the Nigerian Capital Market, with the effect mostly seen in the availability of information to investors and the improvements in the trading patterns of the Nigeria Stock Exchange.

Similarly, Stanford (1999), concluded that the role of information in financial market is a rich and varied one. Two aspect of information in financial system was focused on in his study. First is that stock market makes a great deal of information available which allows decentralization of decisions between shareholders and managers.

Riman, and Eyo (2008) argued whether stock markets promote economic growth; using Granger Casuality test ascertained little evidence of a causal relationship between stock development and economic growth.

Binos (2001) study of promoting purposeful economic development in states and Local Government Council through Capital Market assert the importance of mass awareness of the role the capital market could play in fostering development at various governmental levels.

Ndi-Okere (2006) asserts the performance of the Nigerian capital market in the review of the market activities in the year 2006. Ndi-Okere (2006) reports suggested that there is room for improvement in performance and the capital market could actually propel the desired economic growth.

Okunlola, (2012) asked whether stock market promote economic growth in Nigeria and undertaking a time series data between 1980 to 2000 using the ordinary least square regression technique. The results indicated that there is a positive relationship between growth and all the stock market development variables used. Okunlola, (2012), result showed 
that economic growth in Nigeria is adequately explained by the model specified.

Aga and Kocaman (2008) explained the rationale behind capital market development in emerging markets. Adopting the Efficient Market Hypothesis, they advocated for a market where information is not truncated and operational access is at optimal performance for a meaningful growth to be seen.

Sule, and Momoh, (2009) examined the impact of stock market earnings on Nigeria per capital income. Applying co integration and error correction model technique, their findings shows that both the secondary and primary market play separate roles in the growth of stocks earnings and Nigeria per capital income.

In the same vein, Okunlola (2012) explained the importance of the Nigerian capital in the area of investment generation particularly for business expansion and onward economic growth. Adopting a multi-linear approached, he discovered a positive and significant relationship between the variables of total market capitalization, total stocks traded on the floor of the exchange and economic growth.

Further, the Nigerian Stock Exchange Annual - NSMA (2009) described the opportunities that abound when the capital market is patronized and also the challenges therein. In their theoretical study, the NSMA stated the reasons, features and objectives why the capital market should be a one stop shop where businesses seek capital for expansion while it says awareness and improper record keeping could hinder new business wishing to be enlisted on the floor.

Butler et al (2003) asked whether stock market liquidity matter - taking evidence from seasoned equities in the United State, Butler et al (2003) used a large sample of seasoned equities in the market. It was discovered that, ceteris paribus, investment banks fees are substantially lower for firm with more liquid stock. This evidence provides an important link between stock market liquidity and a component of the firm's cash flows.

Critical in their variable measurement of liquidity of the concerned firm are: 1. Quoted Spread. 2. Relative spread. 3. Quoted depth. 4. Volume. 5. Turnover:

David (1997) in his words, described capital market theory and its relevance to practitioners. He tried to analyses theoretically the tools needed to not only be practitioner but also to participate in the business of capital market.

In the study by Woon and David (2005) of Japan Stock market liquidity and macroeconomics, reviewed a liquidity shock for the period understudied and regarded to be persistent and statistically significant on real balances. Indeed, variance decomposition shows that liquidity shocks explain more than 16 percent of the variation in real balances at a frequency of 18 months. Liquidity shocks have macroeconomic effects which are consistent with persistent money demand shocks. A positive liquidity shock also leads to a statistically significant decline in (nominal) interest rates, consistent with the reduced money demand after the shock. However, the effects of liquidity shocks on asset markets themselves seem more transitory. Liquidity shocks have very short-lived effects on the stock market index (topix), reverting to mean after a couple of periods. It was also found out that market liquidity is significantly affected by shocks to output and topix but not by shocks to money market variables, call rates and real balances. Shocks to topix have a short-lived impact on stock market liquidity, suggesting that a rise in the stock price index attracts liquidity to the stock market at least temporarily. Shocks to economic activity also have significant impacts on stock market liquidity.

Jim (2008) describes the potential of what the capital market can help the economy to achieve through its provision of funds to the real sector. He argued that the engine of growth of any nation lies in her ability to transform the real sector and the capital market is expected to act as a catalyst towards the realization of this goal. Gauging against the fundamental of the capital market and making it perform optimally was the arguments of Meristem Securities Limited (2008).

Pat and James (2010) empirically analyze the impact of the Nigerian capital market on her socio-economic development from 1981 to 2008. The socio-economic development was proxy by the gross domestic product (GDP) while the capital market variables considered included market capitalization, total new issues, volume of transaction and total listed equities and Government stock. Using the ordinary least square it was found that the capital market indices have not impact significantly on the GDP. The government is therefore advised to put up measures to stem up investors' confidence and activities in the market so that it could contribute significantly to the Nigerian socio-economic development.

Al - Faki (2007) described best ways in which the Nigerian capital market can be better understood in terms of its investment practices and regulations. He highlighted the role the capital market is also expected to play and came to a conclusion that the capital market is the engine of growth of the economy.

\section{Methodology}

Data employed in this study is mainly time series sourced from the Central Bank of Nigeria statistical bulletin of various issues, stock exchange market reports, National Bureau of Statistics, relevant journals and textbook. The variables sourced include gross domestic product (at constant basic price), representing the dependent variable and total market capitalization and all share index, representing proxies for the role of capital market. The study also adopts the OLS regression analysis technique for the purpose of estimation.

\subsection{Model Specification}

If we consider a functional model form thus;

$$
\mathrm{GDP}=\mathrm{f}(\text { Mktcap, ASI })
$$

Where:

GDP $=$ Gross Domestic Product

Mktcap $=$ Market capitalization

$\mathrm{ASI}=$ All share index

However, if (i) is linearly expressed in explicitly form; 


$$
\mathrm{GDP}=\alpha_{0}+\beta_{1} \mathrm{MktCap}+\beta_{2} \mathrm{ASI}+\mathrm{u}_{\mathrm{t}}
$$

Where:

GDP $=$ Gross Domestic Product

$\alpha=$ the intercept

$\beta_{1}, \beta_{2}, \beta_{3}, \beta_{4}$ and $\beta_{5}=$ the regression coefficients

$\mathrm{u}=$ error or stochastic term

A priori $\alpha_{1} ; \alpha_{2} ; \alpha_{3}>0$

\subsection{Estimation Method and Empirical Analysis}

Like most econometric data requiring a level of stationarity prior estimation, this study is not an exception. However, the study started with the descriptive estimation of the variables in the study. Thereafter we performed the Augment Dickey Fuller (ADF) unit root test to ascertain the level of stationarity of the variables in the model before testing the level using the OLS regression technique. Conventionally, times series data must certify the unit root test for them to become stationary otherwise, they are subjected to differencing.

ADF Unit Root Test

$\mathrm{Ab}$ initio the order of integration of the individual series is tested owing to the non stationarity characteristics of most time series data. The estimation equation is as given below (Gujarati and Porter 2009).

$$
\Delta \mathrm{Yt}=\beta_{1}+\beta_{2} \mathrm{t}+\delta \mathrm{Y}_{\mathrm{t}-1}+\Sigma \alpha \mathrm{i} \Delta \mathrm{Yt}-\mathrm{I}+f_{\mathrm{t}}(\mathrm{iii})
$$

Where: $f_{\mathrm{t}}=$ is a residual time; $\mathrm{Yt}=$ is the relevant time series; $f_{\mathrm{t}}=$ random error term
Table 1. Descriptive Statistics.

\begin{tabular}{llll}
\hline & GDP & MKTCAP & ASI \\
\hline Mean & 13501.02 & 4113.957 & 190469.4 \\
Median & 7345.478 & 713.7000 & 130901.7 \\
Maximum & 42396.77 & 19077.42 & 605096.4 \\
Minimum & 328.6061 & 16.30000 & 5083.900 \\
Std. Dev. & 13637.05 & 5664.422 & 175355.5 \\
Skewness & 0.945178 & 1.258804 & 0.942544 \\
Kurtosis & 2.550794 & 3.370056 & 3.094717 \\
Jarque-Bera & 3.775232 & 6.475289 & 3.562527 \\
Probability & 0.151432 & 0.039256 & 0.168425 \\
Sum & 324024.5 & 98734.98 & 4571266. \\
Sum Sq. Dev. & $4.28 \mathrm{E}+09$ & $7.38 \mathrm{E}+08$ & $7.07 \mathrm{E}+11$ \\
Observations & 24 & 24 & 24 \\
\hline
\end{tabular}

Source: Eview9 Output

The table represents the descriptive statistics of the variables under review. The Skewness measures the asymmetry of the distribution of the series around its mean, while the Kurtosis measures the normality of the series. For a normal distribution however, the Kurtosis is usually peak at $>3$ and flat at $<3$. Invariably, if the Kurtosis is $>3$, the distribution is peak, otherwise, if it is $<3$ then, the distribution is flat. All series in our study however demonstrates peak distribution. Further, the Jarque - Bera test statistics which test whether the series is normally distributed and measures the difference of the skewness and Kurtosis of the series is normally distributed as indicated from the table.

ADF Unit Root Test Result

\begin{tabular}{|c|c|c|c|c|c|c|c|}
\hline \multirow[t]{2}{*}{ Variable } & \multicolumn{2}{|c|}{ ADFStatistics } & \multirow{2}{*}{$\begin{array}{l}\text { ADFstatistics } \\
1^{\text {st }} \text { Difference } \\
\end{array}$} & & \multicolumn{2}{|l|}{ ADF Statistic } & \multirow{2}{*}{ Order of integration } \\
\hline & Level & Critical values & & Critical values & $2^{\text {nd }}$ Difference & Critical Value & \\
\hline DGDP & & & & & -4.944075 & $\begin{array}{l}\%-3.831511 \\
5 \%-3.029970 \\
10 \%-2.655194\end{array}$ & $\mathrm{I}(2)$ \\
\hline DMKTCAP & & & & & -5.909777 & $\begin{array}{l}1 \%-3.808546 \\
5 \%-3.020686 \\
10 \%-2.650413\end{array}$ & $\mathrm{I}(2)$ \\
\hline ASI & & & & & -6.796504 & $\begin{array}{l}1 \%-3.808546 \\
5 \%-2.020686 \\
10 \%-2.650413\end{array}$ & $\mathrm{I}(2)$ \\
\hline
\end{tabular}

Table 2. ADF Unit Root Test Result.

Source: Eview9 output

In this study, the ADF unit root test was employ to test for the stationarity state of the variables, and the result is as presented in table above. The result of the table shows that all variables demonstrate same level of stationarity state. Gross domestic product (GDP) was not stationary at I(1) but became stationary at I(2). Market capitalization also became stationary at I(2). While All Share Index too became stationary at $\mathrm{I}(2)$.

\begin{tabular}{llll}
\multicolumn{1}{c}{ OLS Result } & & & \\
\hline Variable & Coefficient & Std. Error & t-Statistic \\
\hline C & 4421.138 & 1501.802 & 2.943888 \\
MKTCAP & 2.330417 & 0.303748 & 7.672208 \\
ASI & -0.002664 & 0.009812 & -0.271477 \\
R-squared & 0.884520 & Mean dependent var & 0.0000 \\
Adjusted R-squared & 0.873522 & S. D. dependent var & 0.7887 \\
S. E. of regression & 4849.841 & Akaike info criterion & 13501.02 \\
Sum squared resid & $4.94 \mathrm{E}+08$ & Schwarz criterion & 13637.05 \\
Log likelihood & -236.1330 & Hannan-Quinn criter. & 19.92775 \\
F-statistic & 80.42514 & Durbin-Watson stat & 20.07500 \\
Prob(F-statistic) & 0.000000 & & 19.96682 \\
\hline
\end{tabular}

Source: Eview9 output 
The ordinary regression analysis result as indicated in the table above showed that the variables are jointly positive but mutually exclusively significant. That is, one out of the variable is statistically significant to explain the dependent variable, while the other is not. Specifically, total market capitalization (Mtkcap), which is derived by total sum of the total volume multiply by value of transactions on the floor of the capital market showed from the result a sig $=0.000$. By implication, total market capitalization is statistically significant from the result to explain economic growth having fall within the rejection region of the study 0.05 percent level of significant. Hence, the null hypothesis of no significant relationship between market capitalization and economic growth is rejected and the alternative is accepted. Indeed, the significant level demonstrated by total market capitalization is an indication of improved awareness of capital market activities by local and international companies, organizations and multinationals and; also of the link in what the capital market activities portend for capital accumulation, investment purpose, business expansion and overall economic growth. This result corroborate that of Okpara 2010; Campbell 2010; Ashaolu and Ogunmuyiwa 2010; Okunlola, et al 2013; Ogunbiyi and Okunlola, 2013). Conversely, the second variable of All Share Index (ASI) showed that the null hypothesis of no significant relationship should be accepted and the alternative rejected. This is as indicated from the table that showed a sig value $=0.788$, which is statistically insignificant and also lie within the acceptance region of the preferred 0.05 percent level of significance hence, it is not rejected. As a consequence, ASI is a representation of the total market (broad base) index, that is (a specified number of most capitalized stocks) which reflects a total picture of the behaviours of the common shares quoted on the floor of the Exchange. Basically, ASI is calculated on a daily basis to show how the prices stocks have moved. In Nigeria, ASI tracks the general market movement of all listed equities on the Exchange including those listed on the alternative securities market regardless of capitalization. On the whole, the coefficient of determination denoted by $\mathrm{R}^{2}=0.884$ indicating that there a out 88 percent of explanatory variables is explained on the dependent. As such, a one percent change in the independent variable would vary growth for about 88 percent. In other word, the overall variability of the model is well fitted owing to the level of variance.

\section{Conclusion and Recommendations}

\subsection{Conclusion}

The study has asked whether the activities of the capital market as an impact on the economy growth. The extant literature reviewed and based on the specification of the model, the result attest to the fact that capital market activities, to a great extent, impact on the economy. Specifically, this is indicated by the probability of the total market capitalization, which shows a positive and statistically significant relationship and serves as the combination of the volume of transactions traded. Conversely, the performance of these capitalized stocks calls for improvement in terms of increased securities and instrument in the market as indicated by the ASI. Thus, the ASI, speaks of the quality of the trade that goes on the exchange.

\subsection{Recommendations}

Based on the empirical results of the study, the following are suggested recommendations:

1. There should be deliberate attempt by the authorities at increasing the number of securities traded on the floor of the Exchange to give room for more robust market.

2. Securities so introduced in (1) above should pass quality performance test.

3. There should also be deliberate, increased and constant promotional awareness of the activities, functions, benefits and operations of the market for the general populace.

4. Also, authorities should as a matter (3) above make market penetration easy.

\section{References}

[1] Asaolu, T. O. and Ogunmuyiwa, M. S. (2010) "An Econometric Analysis of the Impact of Macroeconomic Variables on Stock Market Movement in Nigeria". Asian Journal of Business Management, Vol 3. No.1, pp 72-78.

[2] Binos, Y. (2001) "Promoting Purposeful Economic Development in States and Local Government Council through Capital Market". House of Assembly Chambers, (June 2001). Pp 7-9.

[3] CBN (2007) "Capital Market Dynamics in Nigeria: Structure, Transaction Costs and Efficiency 1980 - 2006". Real Sector and Financial Analysis Sector Division, Research and Statistics Department.

[4] CBN (2009) Economic Report for the third quarter of 2009.

[5] CBN (2010) Economic Report for the third quarter of 2010.

[6] Ezirim, B. C. Adebajo, A. Elike, U and Muoghalu, M. I (2009) "Capital Market Growth and Information Technology: Empirical Evidence from Nigeria", International Journal of Business Economics Perspective, Vol.4, No1.

[7] Ogunbiyi, S. S. and Okunlola, F. A. (2013a): "Financial Intermediation and Economic Growth: The Nigerian Experience (1980-2010)" Journal of Management Sciences, June. 2013. Vol. 1, No. 1, p 99-109.

[8] Ogunbiyi, S. S and Okunlola, F. A (2015b): "External Debt and the Capital Accumulation of Nigeria: A Cointegration Approach (1980-2012)". Research Journal of Finance and Accounting, Vol. 6, No.11.

[9] Okonjo - Iweala, (2011): Okonjo-Iweala Frets over Rising Domestic Liabilities, The Nation NewsPaper, August 21 ${ }^{\text {st }}$, 2011. 
[10] Okunlola, F. A., Dangor, B. and Gbanador, M. (2013). "Dividend Policy and Market Price of Shares: Evidence: Evidence from the Nigerian Stock Exchange." Journal of Business and Economic Research, Vol 8. No1, p 125-134, 2013.

[11] Oluwatoyin, M and Gbadebo, O. O. (2009) "The impact of share market capitalization on performance: A case study in the Nigeria confectionary industry", African Journal of Business Management, Vol. 3 (5), pp 220-226.

[12] Onyeiwu, C. (2012): "Domestic Debt and the Growth of Nigerian Economy", Research Journal of Finance and Accounting", Vol. 3, No. 5.

[13] Osaze, E. B. (2007) Capital Markets - African and Global, History, Systems, Practices, Operations, Procedures and Investment Techniques. Lagos: Book House.
[14] Riman, H. B. and Eyo, E. (2008) "Stock Market Performance and Economic Growth in Nigeria; A Causality Investigation". Global Journal of Social Sciences, Vol 7, No. 2, pp 85-91.

[15] Ndi-Okere, O. (2006) "A Review of the Performance of the Nigerian Stock Exchange in 2006". Sourced from www.nigerianstockexchange.org.

[16] NSMA (2002) "Investment Opportunities and Challenges in the Nigerian Capital Market". Nigerian Stock Market Annual, April 2002.

[17] Okpara, G. C. (2010) "Stock Market Prices and the Random Walk Hypothesis: Further Evidence from Nigeria". Journal of Economics and International Finance, Vol. 2, No. 3 pp 049057. 